
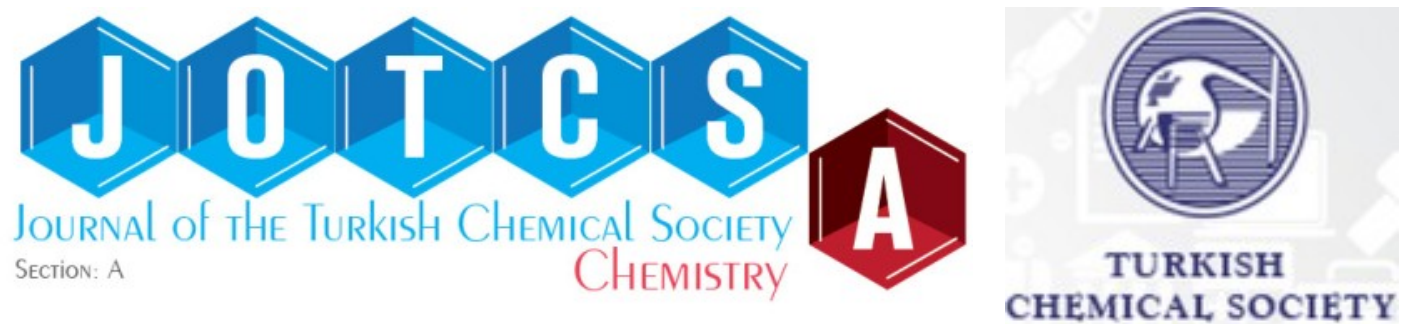

\title{
Synthesis, Characterization, and Adsorption Properties of Highly Microporous Structured Activated Carbon
}

\author{
İlhan KÜçÜK $K^{1,2}$, Yunus ÖNAL ${ }^{3}$ (D) \\ ${ }^{1}$ Department of Chemistry, Faculty of Art and Science, Inonu University, 44280 Malatya, Turkey \\ 2 Muş Alparslan University, 49250, Muş, Turkey \\ ${ }^{3}$ Department of Chemical Engineering, Faculty of Engineering, Inonu University, 44280 Malatya, Turkey
}

\begin{abstract}
The aim of this study is to synthesize activated carbon with high surface area from peach kernel shells which is an agricultural waste. In this study, activated carbon synthesis was carried out by using $\mathrm{CO}_{2}$ at 2 different temperatures $\left(800\right.$ and $\left.900{ }^{\circ} \mathrm{C}\right)$ with physical activation from products carbonized at 4 different temperatures $\left(300,400,500\right.$, and $600{ }^{\circ} \mathrm{C}$ ) and 2 different $\mathrm{N}_{2}$ gas flow rates (100 and 500 $\mathrm{mL} / \mathrm{min}$ ). After carbonization, solid, liquid, and gas yields of the materials were calculated. The surface area of activated carbons synthesized was calculated by BET analysis and the differences in the surface area were shown by changing the synthesis conditions. Surface areas vary between 340.15 and $686.74 \mathrm{~m}^{2} / \mathrm{g}$. In samples pores formed were examined by DFT plus. It was found that most of these pores consist of micropores. Also, the structures of the samples were examined with SEM and XRD analyses. Methylene blue removal of the synthesized samples was studied and the results were compared.
\end{abstract}

Keywords: Biomass, carbonization, physical activation, activated carbon.

Submitted: June 16, 2020. Accepted: July 12, 2021.

Cite this: Küçük İ, Önal Y. Synthesis, Characterization, and Adsorption Properties of Highly Microporous Structured Activated Carbon. JOTCSA. 2021;8(3):821-34.

DOI: https://doi.org/10.18596/jotcsa.753579.

*Corresponding author. E-mail: yunus.onal@inonu.edu.tr.

\section{INTRODUCTION}

Activated carbon, known as activated charcoal, is a high surface area, amorphous and graphite-free carbonaceous compound. Activated carbons, which do not have a chemical formula, differ from each other with their surface areas, advanced and adjustable pores, mechanical strength, high reactive surface chemistry, adsorption capacities, the raw materials they are synthesized, the activation method used and chemicals used (1-5).

One of the most important properties of activated carbons is that they have a porous structure that causes the surface area to grow. Besides its porous structure, pore volume and diameter are important. The formation of pores in activated carbons starts at the carbonization stage. Through physical and chemical activation, these pores gain volume and open if there are closed pores. The formation of the pores is as follows (6):

$\checkmark \quad$ Volatile components in the raw material leave the structure by heating the raw material in an inert environment.

$\checkmark \quad$ These components, which move away from the raw material, pore on the raw material according to the size of the structure.

$\checkmark \quad$ If the displaced structure is in the middle of the solid, the internal pressure will increase in the solid and will open micro channels as this structure moves away.

The pore distribution and pore diameter in an activated carbon vary depending on the type of raw material used and the carbonization temperature (7). 
In recent years, research has been increased towards the use of agricultural waste products for the synthesis of activated carbon. These biomass products are sustainable, cheap, and rich sources of carbon. This feature makes them the suitable raw material for the synthesis of activated carbon. In respect of environmental concern, these agricultural wastes will get decayed finally with time, but most of them reduce slowly and create pollution. The best way to address these issues is to use them as precious material. Along with having a good source of carbon, these biomaterial wastes include other elements and compounds, which can be exploited cleverly according to the application (8). Some agricultural wastes synthesized from activated carbon coffee husks (9), durian shells (10), olive stones (11), rice straw (12), oil palm fibers (13), walnut shells (14), rice husks (15), waste apricot (16), cherry stones (17), banana peels (18), sawdust (19), rice bran (20), almond shells (21), tea waste (22), herb residues (23), corn cobs (24), rice hulls (25), sugarcane bagasse (26), cotton stalks (27), orange peels (28), date stones (29), coconut husks (30), etc.

Activated carbon is an adsorbent acquired from carbonaceous substances with a disorganized crystallographic shape, constituted through randomly dispensed microcrystals. This microcrystalline shape is constructed from standard systems which include graphene sheets and fullerene or quasi-graphitic fragments. However, this microcrystalline association does now no longer enlarge on a macroscopic scale ensuing in a disordered and surprisingly nanoporous shape. Consequently, those substances gift excessive surface area, extensive type of practical groups and a pore length distribution. All those traits supply them an outstanding potential to adsorb a remarkable range of molecules (31). In addition to this potential, it is used in many different fields. Some of those purification (32), nuclear power stations (33), gas separation (34), energy storage (35), catalysis (36), water treatment (37), pharmaceutical (38), capacitors (39), petroleum industries (40), etc.

Adsorption, which is one of the most used areas of activated carbons, takes place through the pores on the surface of the activated carbon. The substance to be adsorbed enters through these pores and interacts with the outer surface of the activated carbon and adheres to that region. Adsorption takes place in this manner. However, for the adsorption to take place, the material to be adsorbed must pass through the pores of the activated carbon. If these pores are small or if the material to be adsorbed is larger than the pores, adsorption cannot take place (41).

In this study, activated carbon synthesis was made from peach kernel shells which are agricultural waste. In this study, carbonization temperature, carbonization gas flow and activation temperature were changed. The synthesized active carbons were compared with each other.

\section{EXPERIMENTAL}

\section{Synthesis of the Activated Carbon}

Supplied with peach kernel shells (Bursa, Turkey) was used without applying any pretreatment except for washing with water. These shells were firstly subjected to pyrolysis process and the synthesis of activated carbon was made on solid char. A threezone furnace was used for the pyrolysis process of peach kernel shell. The furnace was placed in the steel reactor with the help of a steel cuvette by taking approximately $500 \pm 25 \mathrm{~g}$ and subjected to pyrolysis in nitrogen atmosphere. Pyrolysis was carried out at 300,400, 500, and $600{ }^{\circ} \mathrm{C}$. The furnace started at room temperature and increased to $10^{\circ} \mathrm{C}$ per minute to the final temperature. When it reached the final temperature, the furnace remained stable for 1 hour and was then allowed to cool to room temperature. Nitrogen gas atmosphere was used in all of these processes and nitrogen gas flow was made with the help of a manometer. Nitrogen gas for the samples was tested by means of manometer pyrolysis at 100 and $500 \mathrm{~mL} / \mathrm{min}$ gas flow rates. The pyrolysis liquid was collected by means of the back cooler connected to the outlet end of the steel reactor.

Char obtained was placed in a three-zone furnace by means of a glass reactor and the physical activation was carried out. Two different activation temperatures ( 800 and $900{ }^{\circ} \mathrm{C}$ ) were studied. At these temperatures, $\mathrm{CO}_{2}$ gas was used for activation and the gas flow was fixed to a flow of $100 \mathrm{~mL} / \mathrm{min}$ by means of a manometer. In this activation process, the furnace increased from $10^{\circ} \mathrm{C}$ per minute starting from room temperature and remained at the final temperature for 1 hour.

\section{Preparation of Methylene Blue}

The methylene blue used in the study was placed in a beaker and kept in an oven at $105^{\circ}$ for 6 hours. Then 1 gram of methylene blue was taken and 1000 ppm, 1 liter stock solution was prepared.

\section{Adsorption}

The prepared stock solution was diluted to $100 \mathrm{ppm}$ and 0,1 grams of activated carbon sample was added to $100 \mathrm{~mL}$ and mixed for approximately 24 hours by magnetic stirrer $(\mathrm{pH} 6.2$ at room temperature). The received solutions were filtered through a syringe filter and measured at $660 \mathrm{~nm}$ in a UV-Vis device.

\section{Equipment}

Carbonization process with Protherm PZF 12/50/700 furnace, activation process with Protherm PZF $12 / 60 / 600$ furnace were carried out. 


\section{Analysis}

UV-Vis analyses were performed with a Shimadzu UV-2100S, SEM analyses were carried out with a Leo EV040 brand scanning electron microscope, XRD were realized with a Rigaku RadB-DMAX II computer-controlled X-ray diffractometer, and BET (Brunauer-Emmett-Teller) measurements were performed with a Micromeritics Tristar 3000, and elemental analyses were realized with a CHNS-932 (LECO) Elemental Analyzer.

\section{RESULTS AND DISCUSSION}

Biomass is converted to solid (char), liquid, and gas by pyrolysis process. These transformations vary depending on the biomass species and pyrolysis conditions. Table 1 shows the solid, liquid, and gas transformations of the peach kernel shell used as raw material as a result of the process.

Table 1: Solid, liquid and gas yields as a result of pyrolysis process.

\begin{tabular}{cccc}
\hline Temperature / $\mathbf{~ N}_{\mathbf{2}}$ Gas Flow & Solid Yield \% & Liquid Yield \% & Gas Yield \% \\
\hline $300^{\circ} \mathrm{C} / 100 \mathrm{~mL} / \min$ & 41.5 & 39.91 & 18.59 \\
$300^{\circ} \mathrm{C} / 500 \mathrm{~mL} / \min$ & 43.02 & 37.55 & 19.43 \\
$400^{\circ} \mathrm{C} / 100 \mathrm{~mL} / \mathrm{min}$ & 34.24 & 37.04 & 28.72 \\
$400^{\circ} \mathrm{C} / 500 \mathrm{~mL} / \mathrm{min}$ & 33.62 & 34.22 & 32.16 \\
$500^{\circ} \mathrm{C} / 100 \mathrm{~mL} / \mathrm{min}$ & 29.55 & 33.1 & 37.35 \\
$500^{\circ} \mathrm{C} / 500 \mathrm{~mL} / \mathrm{min}$ & 29.01 & 36.17 & 34.82 \\
$600^{\circ} \mathrm{C} / 100 \mathrm{~mL} / \mathrm{min}$ & 27.03 & 37.25 & 35.72 \\
$600^{\circ} \mathrm{C} / 500 \mathrm{~mL} / \mathrm{min}$ & 27.03 & 31.29 & 41.68 \\
\hline
\end{tabular}

Peach kernel shell was subjected to pyrolysis at four different temperatures $\left(300,400,500\right.$, and $600{ }^{\circ} \mathrm{C}$ ) and solid, liquid and gas yields were calculated. Solid yield decreased with increasing temperature. It is seen that gas yield increases while liquid yield decreases with increasing temperature. Although the change in pyrolysis gas flow rate changed the solid, liquid and gas yields excessively at some temperatures, the change in some temperatures was very low.

The BET analysis results of the synthesized activated carbons are shown in Table 2. According to these results, the surface area varies between 686.74 and $340.15 \mathrm{~m}^{2} / \mathrm{g}$. The highest surface area was achieved at an activation temperature of 800 ${ }^{\circ} \mathrm{C}$ in $\mathrm{N}_{2}$ gas flow of $100 \mathrm{~mL} / \mathrm{min}$ at $500{ }^{\circ} \mathrm{C}$ carbonization temperature. Table 2 shows that the change in temperature of pyrolysis caused changes in surface areas. Increasing the pyrolysis temperature up to $500{ }^{\circ} \mathrm{C}$ caused a positive change in the surface areas, while the rise to $600{ }^{\circ} \mathrm{C}$ showed a negative change in the surface areas. The change in the gas flow rate of pyrolysis caused changes in the samples. There was no order in these changes. The increased gas flow rate, except for 2 samples, caused a decrease in surface areas. The change in the activation temperature caused the surface area to change. In particular, the increase in activation temperature increased the surface area of samples. Since one of the objectives in activated carbons is the increased surface, it is necessary to work at high activation temperature when using $\mathrm{CO}_{2}$ for high surface area activated carbons. Also, when we look at the synthesized activated carbons, we can usually mention two types of pores. Table 2 shows that activated carbons are composed of micropore and mesopore. Some samples were found to consist entirely of micropores. In particular, the activated carbon synthesized at low carbonization temperature and low activation temperature is entirely composed of micropores. Increased carbonization temperature increased mesopore formation. Also, the increased gas flow rate increased the amount of mesopore in the samples. Another parameter, namely activation temperature, positively affected mesopore formation. Table 2 shows the total volume, micro and meso volumes of the activated carbons. Almost all of the samples consisted of micro volumes. In some samples, meso volumes were not observed at all, whereas in some samples a small amount was observed. Increased activation temperature caused micro volume to increase.

In the literature (42), activated carbon synthesis have been made from peach kernel shell. However, chemical activation method was generally used in these studies. In very few physical activation the results of activation temperature and carbonization temperature on activated carbon using $\mathrm{CO}_{2}$ were not investigated. In some studies, physical activation was performed with water vapor. However, even with this activation, the activated carbons synthesized differ from each other. Compared with the studies in the literature, this study showed differences in many ways. The surface areas of the synthesized activated carbons were smaller than those synthesized by chemical activation in the literature (43). This is due to the fact that the chemical agent can directly contact the surface while the $\mathrm{CO}_{2}$ hits the surface. However, during this contact, the chemical agent affected the surface and the active carbons have increased the ratio of mesopore. In this study, the amount of mesopore is less. In the literature (31), water vapor is used in activated carbons synthesized by physical activation. It is seen that the use of water vapor 
causes more development of pores. When the water molecule contacted the biomass, it caused the pores to grow by contacting the pore walls in the cavities formed by carbonization. However, since the $\mathrm{CO}_{2}$ molecule was larger than the water molecule, it could not provide expansion in the walls and expanded into the pore center. Therefore, the amount of mesopore is very high in water vapor studies in the literature. As the surface area will increase with increasing mesopore amount, the surface area in these studies is higher than the surface areas of the synthesized active carbons.

Figure 1 shows that the pore distribution ranges in the samples. Samples generally have pore distributions ranging from $1 \mathrm{~nm}$ to $2 \mathrm{~nm}$. These pore distributions show the micropores formed in the structure. As in Table 2, the micropore ratio was found to be high in the samples. These results showed parallelism with the pore distribution graph and confirmed the structure.

One of the ways of characterizing activated carbons is N2 adsorption graphs. N2 adsorption graphs provide information about the pores of activated carbons. Six types of adsorption plots were defined by IUPAC (International Union of Pure and Applied Chemistry). Each graph tells us about the pores of activated carbons by following different N2 adsorption. N2 adsorption graphs of the synthesized activated carbons are given in Figure 2. According to the graph in Figure 2, the N2 adsorption graph is similar to type 1 . Type 1 graphs are generally N2 adsorption graphs seen in microporous and low surface area activated carbons. In the graph, adsorption at low pressure increases rapidly. This increase is due to microporous. The adsorption stops with the filling of micropores in the structure and the graph proceeds in a straight way. 
Table 2: BET analysis results of activated carbons.

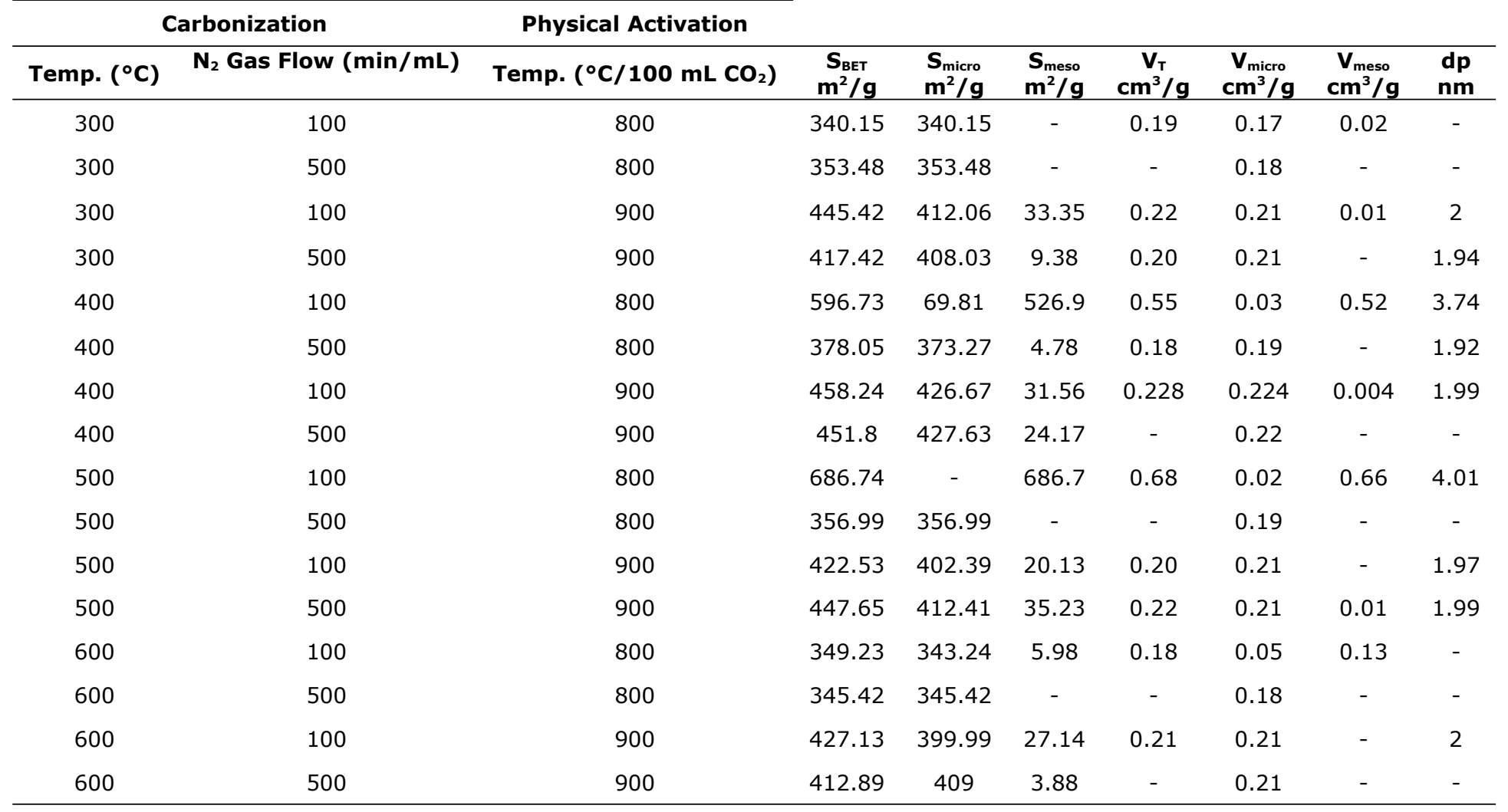




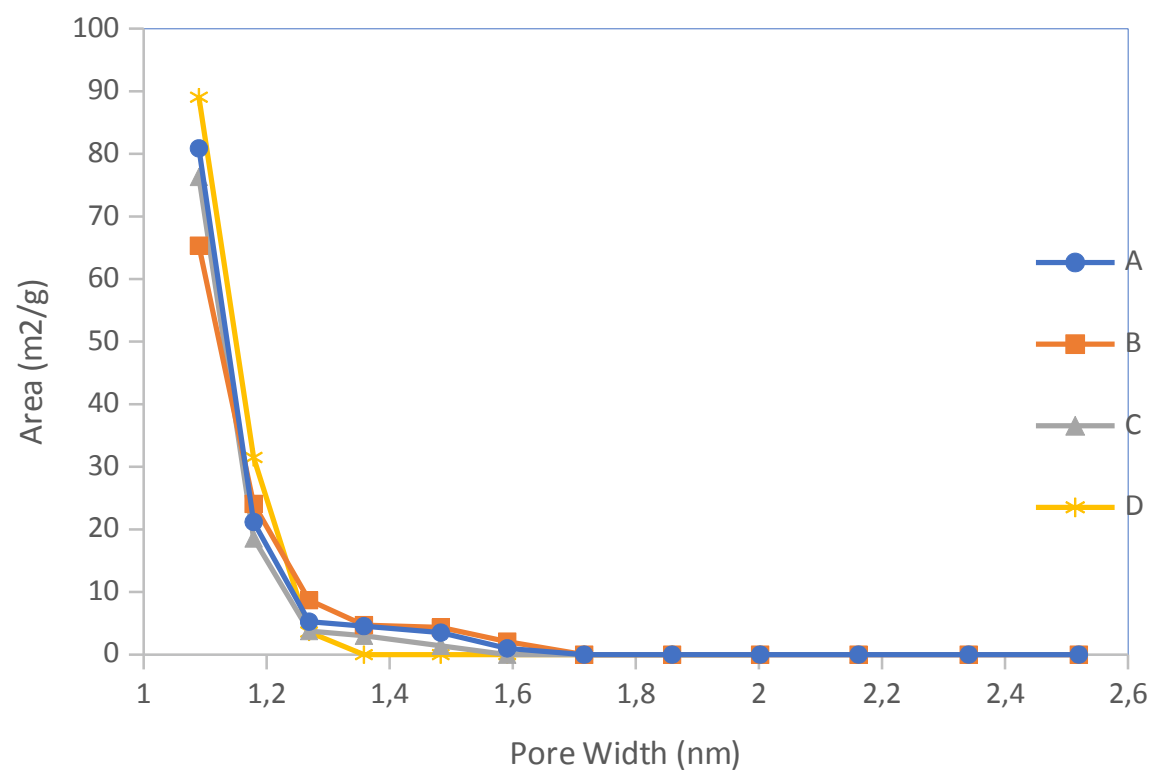

Figure 1: Pore size distribution of activated carbon sample A. Activated carbon sample at $500{ }^{\circ} \mathrm{C} 100$ $\mathrm{mL} / \mathrm{min} \mathrm{N}_{2}$ carbonization and at $900{ }^{\circ} \mathrm{C}$ with $100 \mathrm{~mL} / \mathrm{min} \mathrm{CO}$ activation B. Activated carbon sample at $400{ }^{\circ} \mathrm{C} 100 \mathrm{~mL} / \mathrm{min} \mathrm{N}_{2}$ carbonization and at $900^{\circ} \mathrm{C}$ with $100 \mathrm{~mL} / \mathrm{min} \mathrm{CO}_{2}$ activation C. Activated carbon sample at $600{ }^{\circ} \mathrm{C} 100 \mathrm{~mL} / \mathrm{min} \mathrm{N}_{2}$ carbonization and at $800^{\circ} \mathrm{C}$ with $100 \mathrm{~mL} / \mathrm{min} \mathrm{CO} \mathrm{C}_{2}$ activation D. Activated carbon sample at $300{ }^{\circ} \mathrm{C} 100 \mathrm{~mL} / \mathrm{min} \mathrm{N}$ carbonization and at $800{ }^{\circ} \mathrm{C}$ with $100 \mathrm{~mL} / \mathrm{min} \mathrm{CO}_{2}$ activation.

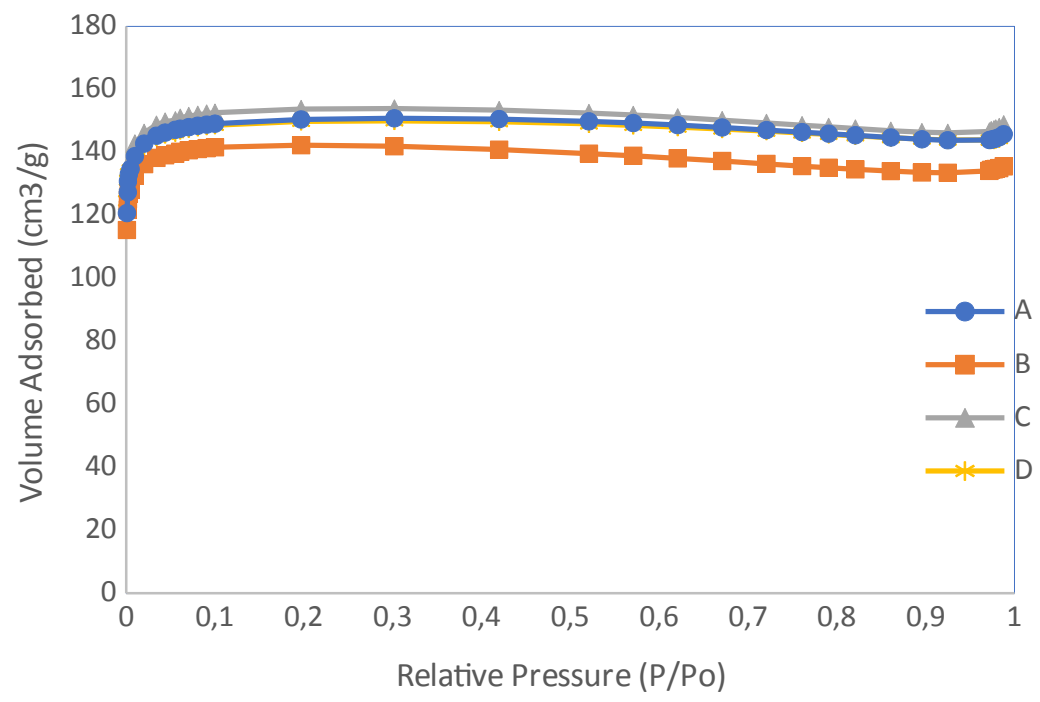

Figure 2: Adsorption isotherms of $\mathrm{N}_{2}$ A. Activated carbon sample at $500{ }^{\circ} \mathrm{C} 500 \mathrm{~mL} / \mathrm{min} \mathrm{N}_{2}$ carbonization and at $900{ }^{\circ} \mathrm{C}$ with $100 \mathrm{~mL} / \mathrm{min} \mathrm{CO}_{2}$ activation B. Activated carbon sample at $500{ }^{\circ} \mathrm{C} 100$ $\mathrm{mL} / \mathrm{min} \mathrm{N}_{2}$ carbonization and at $900{ }^{\circ} \mathrm{C}$ with $100 \mathrm{~mL} / \mathrm{min} \mathrm{CO}_{2}$ activation C. Activated carbon sample at $400{ }^{\circ} \mathrm{C} 100 \mathrm{~mL} / \mathrm{min} \mathrm{N}_{2}$ carbonization and at $900^{\circ} \mathrm{C}$ with $100 \mathrm{~mL} / \mathrm{min} \mathrm{CO}_{2}$ activation D. Activated carbon sample at $300{ }^{\circ} \mathrm{C} 100 \mathrm{~mL} / \mathrm{min} \mathrm{N}_{2}$ carbonization and at $900{ }^{\circ} \mathrm{C}$ with $100 \mathrm{~mL} / \mathrm{min} \mathrm{CO}_{2}$ activation. 

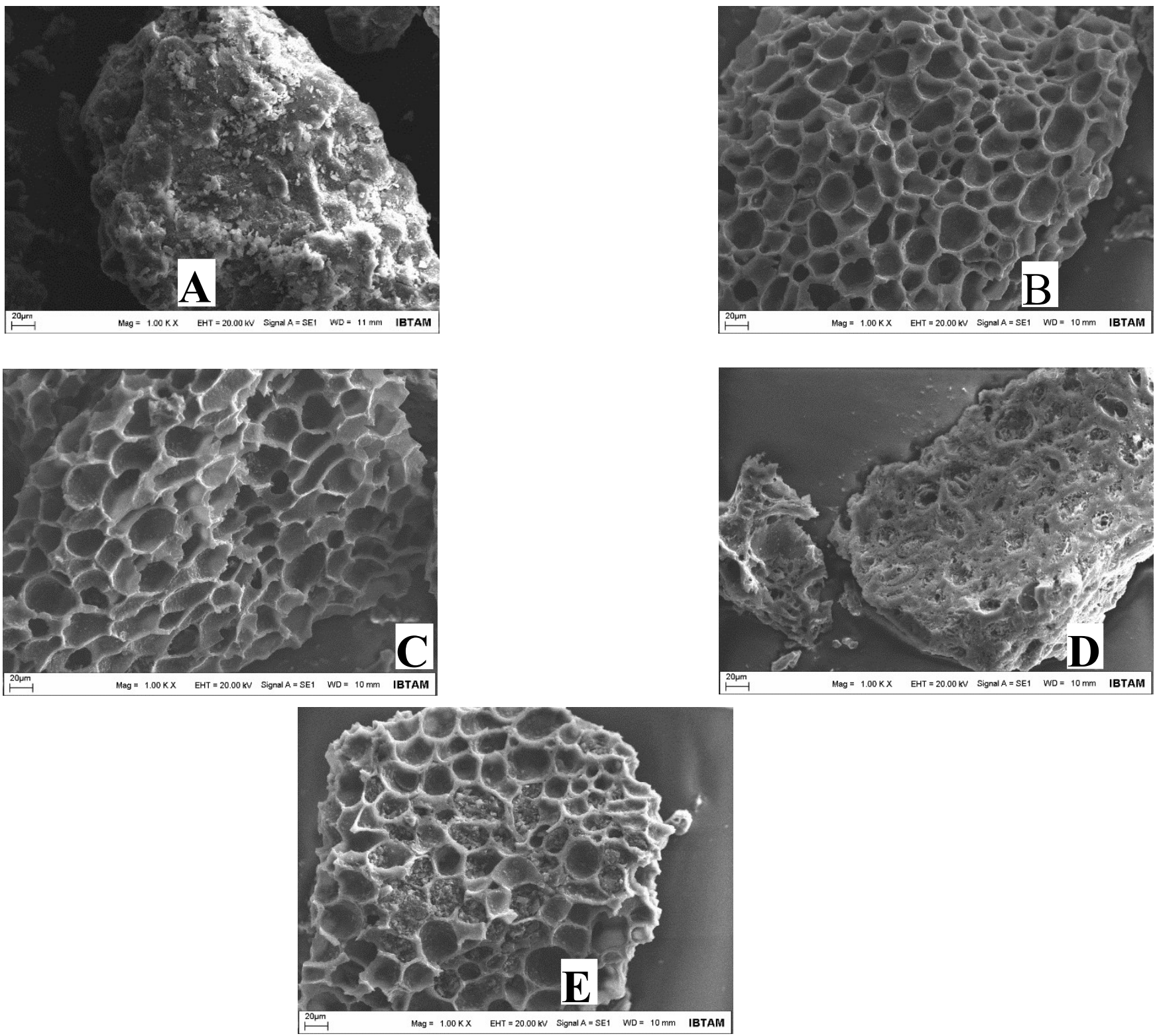

Figure 3: A. SEM image of raw peach shell B. Activated carbon sample at $500{ }^{\circ} \mathrm{C} 100 \mathrm{~mL} / \mathrm{min} \mathrm{N}_{2}$ carbonization and at $800^{\circ} \mathrm{C}$ with $100 \mathrm{~mL} / \mathrm{min} \mathrm{CO}$ activation C. Activated carbon sample at $500{ }^{\circ} \mathrm{C} 500$ $\mathrm{mL} / \mathrm{min} \mathrm{N}_{2}$ carbonization and at $900{ }^{\circ} \mathrm{C}$ with $100 \mathrm{~mL} / \mathrm{min} \mathrm{CO}_{2}$ activation. D. Activated carbon sample at 400 ${ }^{\circ} \mathrm{C} 100 \mathrm{~mL} / \mathrm{min} \mathrm{N}_{2}$ carbonization and at $800{ }^{\circ} \mathrm{C}$ with $100 \mathrm{~mL} / \mathrm{min} \mathrm{CO}_{2}$ activation. E. Activated carbon sample at $400{ }^{\circ} \mathrm{C} 100 \mathrm{~mL} / \mathrm{min} \mathrm{N}_{2}$ carbonization and at $900{ }^{\circ} \mathrm{C}$ with $100 \mathrm{~mL} / \mathrm{min} \mathrm{CO}_{2}$ activation. 


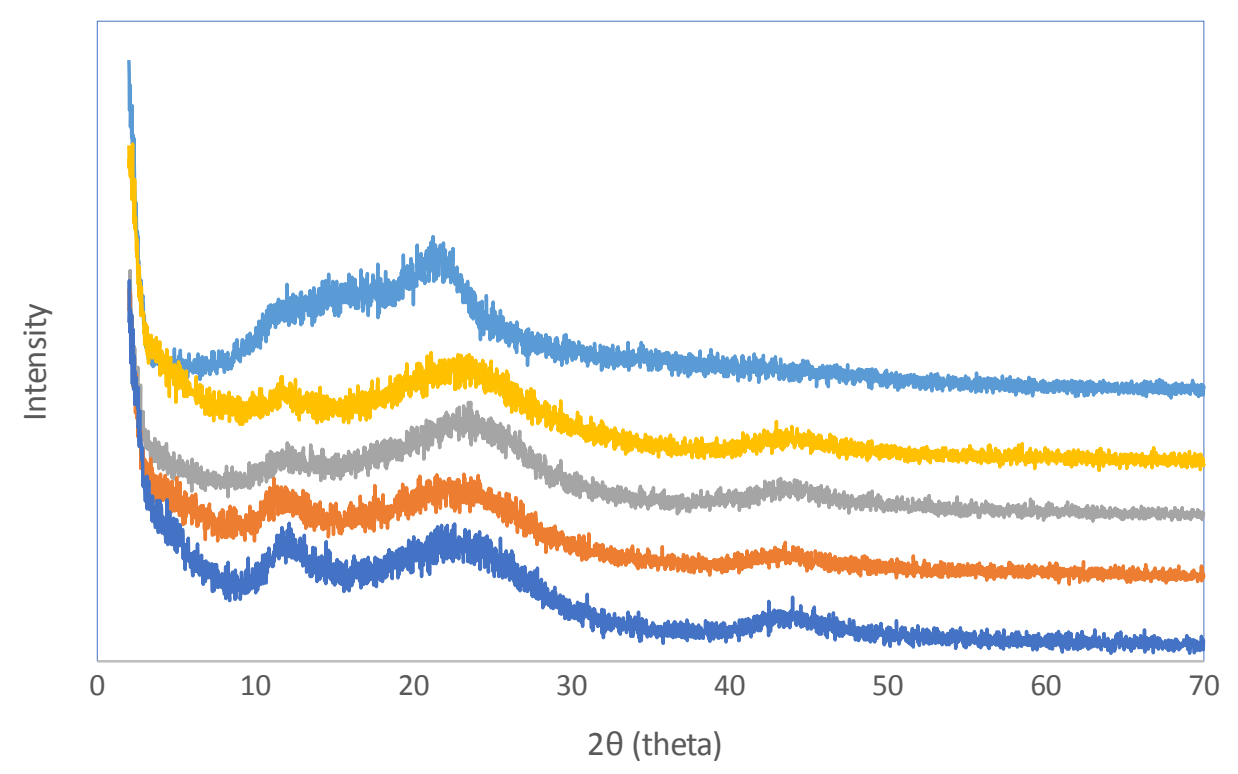

Figure 4: XRD chart of samples. A. XRD chart of raw peach shell. B. Activated carbon sample at $400{ }^{\circ} \mathrm{C}$ $100 \mathrm{~mL} / \mathrm{min} \mathrm{N} \mathrm{N}_{2}$ carbonization and at $800{ }^{\circ} \mathrm{C}$ with $100 \mathrm{~mL} / \mathrm{min} \mathrm{CO}_{2}$ activation. C. Activated carbon sample at $400{ }^{\circ} \mathrm{C} 100 \mathrm{~mL} / \mathrm{min} \mathrm{N}_{2}$ carbonization and at $900{ }^{\circ} \mathrm{C}$ with $100 \mathrm{~mL} / \mathrm{min} \mathrm{CO}_{2}$ activation. D. Activated carbon sample at $500{ }^{\circ} \mathrm{C} 100 \mathrm{~mL} / \mathrm{min} \mathrm{N} \mathrm{N}_{2}$ carbonization and at $800{ }^{\circ} \mathrm{C}$ with $100 \mathrm{~mL} / \mathrm{min} \mathrm{CO}_{2}$ activation. E. Activated carbon sample at $500{ }^{\circ} \mathrm{C} 500 \mathrm{~mL} / \mathrm{min} \mathrm{N}_{2}$ carbonization and at $900{ }^{\circ} \mathrm{C}$ with $100 \mathrm{~mL} / \mathrm{min} \mathrm{CO}_{2}$ activation

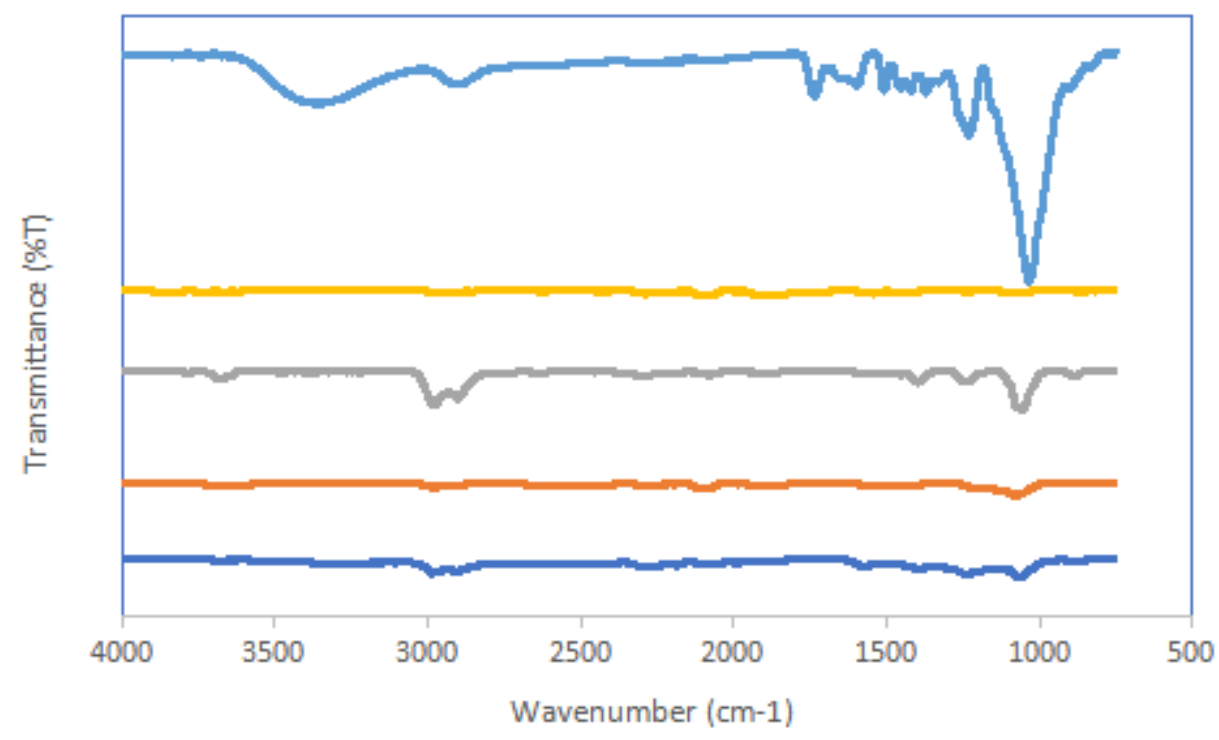

Figure 5: FTIR spectra of raw material and activated carbon samples. A. Raw material. B. Activated carbon sample at $400{ }^{\circ} \mathrm{C} 100 \mathrm{~mL} / \mathrm{min} \mathrm{N} \mathrm{N}_{2}$ carbonization and at $800^{\circ} \mathrm{C}$ with $100 \mathrm{~mL} / \mathrm{min} \mathrm{CO}_{2}$ activation. C. Activated carbon sample at $400{ }^{\circ} \mathrm{C} 100 \mathrm{~mL} / \mathrm{min} \mathrm{N}_{2}$ carbonization and at $900^{\circ} \mathrm{C}$ with $100 \mathrm{~mL} / \mathrm{min} \mathrm{CO}_{2}$ activation. D.

Activated carbon sample at $500{ }^{\circ} \mathrm{C} 100 \mathrm{~mL} / \mathrm{min} \mathrm{N}$ carbonization and at $800{ }^{\circ} \mathrm{C}$ with $100 \mathrm{~mL} / \mathrm{min} \mathrm{CO}_{2}$ activation. E. Activated carbon sample at $500{ }^{\circ} \mathrm{C} 500 \mathrm{~mL} / \mathrm{min} \mathrm{N}_{2}$ carbonization and at $900{ }^{\circ} \mathrm{C}$ with 100 $\mathrm{mL} / \mathrm{min} \mathrm{CO}_{2}$ activation.

One of the methods used to characterize activated carbons is SEM analysis. Thanks to SEM analysis, we see the pores of the activated carbons. SEM images of the synthesized activated carbons and peach kernel shell used as raw materials are shown in Figure 3. According to SEM images, peach kernel shell does not show pores on its surface without any pretreatment. The formation of pores on the surface is seen as a result of activated carbon synthesis.

XRD analysis of synthesized activated carbons and peach kernel shell is shown in Figure 4 . When the raw materials and activated carbons were examined, no crystalline structure was found in the 
structure. Amorphous is observed in the structures. In the peach kernel shell used in the synthesis of activated carbon, a small amount of regular structure is encountered. In particular, the peak of about $22^{\circ}$ is defined as the cellulose peak and is seen in cellulose-structured materials. During the synthesis of activated carbon, this regular structure was disrupted by heat and partially lost this peak intensity in activated carbon samples.

The FTIR spectroscopy technique was used to identify the functional groups on the surface on activated carbons and the raw material. According to the FTIR spectra in Figure 5, the band belongs to $\mathrm{OH}$ stress vibrations at approximately $3450 \mathrm{~cm}^{-1}$ band around $2850 \mathrm{~cm}^{-1}$ indicates the $\mathrm{C}-\mathrm{H}$ stretching vibrations, the band seen at about $1700 \mathrm{~cm}^{-1}$ originates from $\mathrm{C}=\mathrm{O}$, band at about $1600 \mathrm{~cm}^{-1}$ belongs to the $\mathrm{C}=\mathrm{C}$ bond vibration of alkenes. Band at about $1000 \mathrm{~cm}^{-1}$ is the peak of vibrations caused by $\mathrm{C}-\mathrm{OH}$ and $\mathrm{C}-\mathrm{O}-\mathrm{C}$ bonds.

Elemental analysis results of synthesized activated carbons and raw material are given in Table 3 . According to Table 3, It is seen that the carbon amounts of the synthesized activated carbons are approximately $7-71 \%$ higher than the raw materials. In addition, the carbon content of the synthesized activated carbons that are exposed to a high activation temperature is generally less than the others. Activated carbons synthesized at the same carbonization temperature and activation temperature of $800{ }^{\circ} \mathrm{C}$ appear to reduce the amount of carbon at an increased gas flow rate. However, at the activation temperature of $900{ }^{\circ} \mathrm{C}$ this was the opposite. The hydrogen content of the synthesized active carbons decreased approximately 5 times compared to the raw material.

Adsorption, which is one of the most commonly used application fields of activated carbons, was studied. In this work, methylene blue adsorption capacities of activated carbons were examined. The adsorption capacity of the synthesized activated carbons was found to be very low. The reason for this is methylene blue, which is the molecule to be adsorbed, and the reason is the diameter of the pores formed on the activated carbon. If the molecule to be adsorbed passes through the pores on the activated carbon, it will bind to the atoms on the outer surface of the pores through secondary interactions. Because the methylene blue molecule did not pass through the pores on the activated carbon this phenomenon could not occur. The synthesized activated carbons have very small pore diameters. DFT results show how small and narrow the pore diameters change. Therefore, these results are quite natural.

\section{CONCLUSIONS}

In this study, it is aimed to synthesize activated carbon with narrow pore distribution from peach seed peel, which is an agricultural waste. In the study, carbonization was made at 4 different temperatures and 2 different gas flows, and $\mathrm{CO} 2$ was used for activation. As a result of the characterization of the samples, it was observed that micropores were abundant and showed a narrow pore distribution according to the DFT plus data. The micropore ratio in the prepared activated carbons varied depending on the temperature and gas flow rate. No micropores were observed in one sample, although some samples consisted entirely of micropores. In the elemental analysis of activated carbons, the amount of carbon showed a maximum increase of $71 \%$ compared to the raw material. In the study, the adsorption capacity of methylene blue studied in the samples with narrow pore distribution was quite low, while adsorption was not observed in some samples. Although the activated carbons prepared in this study are not suitable for methylene blue adsorption, it can be checked whether they are suitable by using different applications. 
Table 3: Elementary analysis results of raw materials and activated carbons.

\begin{tabular}{|c|c|c|c|c|c|c|}
\hline \multicolumn{2}{|c|}{ Carbonization } & \multirow{2}{*}{$\begin{array}{c}\text { Physical } \\
\text { Activation } \\
\text { Temperature } \\
\left({ }^{\circ} \mathrm{C} / 100 \mathrm{~mL}\right. \\
\left.\mathrm{CO}_{2}\right)\end{array}$} & \multirow[b]{2}{*}{ C } & \multirow[b]{2}{*}{$\mathbf{H}$} & \multirow[b]{2}{*}{$\mathbf{N}$} & \multirow[b]{2}{*}{$\mathbf{s}$} \\
\hline $\begin{array}{c}\text { Temperature } \\
{ }^{\circ} \mathrm{C}\end{array}$ & $\begin{array}{c}\mathbf{N}_{2} \text { Gas } \\
\text { Flow } \\
\text { dk/mL }\end{array}$ & & & & & \\
\hline & Raw Materials & & 50.45 & 5.68 & 0.072 & - \\
\hline 300 & 100 & 800 & 79.27 & 1.03 & 0.28 & - \\
\hline 300 & 500 & 800 & 78.25 & 1.132 & 0.32 & - \\
\hline 300 & 100 & 900 & 54.07 & 1.317 & 0.184 & - \\
\hline 300 & 500 & 900 & 57.74 & 1.063 & 0.242 & - \\
\hline 400 & 100 & 800 & 86.27 & 0.98 & - & - \\
\hline 400 & 500 & 800 & 74.85 & 1.628 & 0.276 & - \\
\hline 400 & 100 & 900 & 62.06 & 0.59 & - & - \\
\hline 400 & 500 & 900 & 69.40 & 1.219 & 0.132 & - \\
\hline 500 & 100 & 800 & 86.53 & 0.97 & - & - \\
\hline 500 & 500 & 800 & 79.76 & 1.607 & 0.268 & - \\
\hline 500 & 100 & 900 & 65.90 & 1.509 & 0.138 & 0.053 \\
\hline 500 & 500 & 900 & 74.34 & 0.64 & - & - \\
\hline 600 & 100 & 800 & 84.00 & 1.39 & 0.215 & - \\
\hline 600 & 500 & 800 & 77.46 & 1.412 & 0.259 & - \\
\hline 600 & 100 & 900 & 76.81 & 0.59 & - & - \\
\hline 600 & 500 & 900 & 82.77 & 1.009 & 0.173 & 0.054 \\
\hline
\end{tabular}

Table 4: Methylene blue adsorption capacity of activated carbons.

\begin{tabular}{|c|c|c|c|c|}
\hline \multicolumn{2}{|c|}{ Carbonization } & \multirow{2}{*}{$\begin{array}{c}\text { Physical Activation } \\
\text { Temperature } \\
\left({ }^{\circ} \mathrm{C} / 100 \mathrm{~mL} \mathrm{CO}_{2}\right) \\
\end{array}$} & \multirow[b]{2}{*}{$\begin{array}{c}S_{\text {BET }} \\
\mathbf{m}^{2} / \mathbf{g}\end{array}$} & \multirow[b]{2}{*}{$\begin{array}{l}\text { Adsorption Capacity } q_{\mathrm{e}} \\
\text { ( } \mathrm{mg} / \mathrm{g})\end{array}$} \\
\hline $\begin{array}{l}\text { Temperature } \\
{ }^{\circ} \mathrm{C}\end{array}$ & $\begin{array}{l}\mathbf{N}_{2} \text { Gas } \\
\text { Flow } \\
\text { dk/mL }\end{array}$ & & & \\
\hline 300 & 100 & 800 & 340.15 & 2.98 \\
\hline 300 & 500 & 800 & 353.48 & 0.89 \\
\hline 300 & 100 & 900 & 445.42 & 12 \\
\hline 300 & 500 & 900 & 417.42 & 9.69 \\
\hline 400 & 100 & 800 & 596.73 & 1.44 \\
\hline 400 & 500 & 800 & 378.05 & - \\
\hline 400 & 100 & 900 & 458.24 & 24.1 \\
\hline 400 & 500 & 900 & 451.8 & 16.29 \\
\hline 500 & 100 & 800 & 686.74 & - \\
\hline 500 & 500 & 800 & 356.99 & - \\
\hline 500 & 100 & 900 & 422.53 & 9.69 \\
\hline 500 & 500 & 900 & 447.65 & 7.74 \\
\hline 600 & 100 & 800 & 349.23 & - \\
\hline 600 & 500 & 800 & 345.42 & - \\
\hline 600 & 100 & 900 & 427.13 & 8.15 \\
\hline 600 & 500 & 900 & 412.89 & 7.93 \\
\hline
\end{tabular}




\section{ACKNOWLEDGEMENT}

This study was supported by the unit of Scientific Researches of Inonu University in Malatya, Turkey; Project no: FDI-2017-680

\section{REFERENCES}

1. Ayinla RT, Dennis J, Zaid H, Sanusi Y, Usman F, Adebayo $L$. A review of technical advances of recent palm bio-waste conversion to activated carbon for energy storage. Journal of cleaner production.

2019;229:1427-42. $\leq \mathrm{DOl}>$

2. Mayyas M, Sahajwalla V. Carbon nano-sponge with enhanced electrochemical properties: A new understanding of carbon activation. Chemical Engineering Journal. 2019;358:980-91. <DOl>

3. Khan JH, Marpaung F, Young C, Lin J, İslam MT, Alsheri SM, Ahamad T, Alhokbany N, Ariga K, Shrestha LK, Yamauchi Y, W. Wu KC, Hossain MSA, $\mathrm{Kim}$ J. Jute-derived microporous/mesoporous carbon with ultra-high surface area using a chemical activation process. Microporous Mesoporous Materials. 2019;274:251-6. $\leq \mathrm{DOl}>$

4. Zhang $Y$, Song $X, X u Y$, Shen $H$, Kong $X$, Xu H. Utilization of wheat bran for producing activated carbon with high specific surface area via $\mathrm{NaOH}$ activation using industrial furnace. Journal of cleaner production. 2019;210:366-75. $\leq \mathrm{DOl}>$

5. Sharma M, Joshi M, Nigam S, Shree S, Avasthi DK, Adelung R, Srivastava SK, Mishra YK. ZnO tetrapods and activated carbon based hybrid composite: Adsorbents for enhanced decontamination of hexavalent chromium from aqueous solution. Chemical Engineering Journal. 2019;358:540-51. <DOl>

6. Abdullah MO, Tan IW, Lim LS. Automobile adsorption air-conditioning system using oil palm biomass-based activated carbon: a review. Renewable Sustainable Energy Reviews. 2011; 15:2061-72. $\leq$ DOI $>$
7. Hu Z, Srinivasan M. Mesoporous high-surfacearea activated carbon. Microporous Mesoporous Materials. 2001;43:267-75. $\leq \mathrm{DOl}>$

8. Sinha P, Banerjee S, Kar K.K. Characteristics of activated carbon. Springer Series in Materials Science. 2020. ISBN: 978-3-030-43009-2

9. Oliveira L, Pereira E, Guimaraes R, Vallone A, Pereira M, Mesquita JP, Sapag K. Preparation of activated carbons from coffee husks utilizing $\mathrm{FeCl} 3$ and $\mathrm{ZnCl} 2$ as activating agents. Journal of Hazardous Materials. 2009;165;87-94. <DOl $>$

10. Chandra TC, Mirna M, Sudaryanto Y, Ismadji S. Adsorption of basic dye onto activated carbon prepared from durian shell: Studies of adsorption equilibrium and kinetics. Chemical Engineering Journal. 2007;127:121-9. $\leq \mathrm{DOI}>$

11. Martinez ML, Torres MM, Guzman CA, Maestri DM. Preparation and characteristics of activated carbon from olive stones and walnut shells. Industrial crops products. 2006;23:23-8. $\leq \mathrm{DOI}>$

12. Gao P, Liu Z-H, Xue G, Han B, Zhou M-H. Preparation and characterization of activated carbon produced from rice straw by $(\mathrm{NH} 4) 2 \mathrm{HPO} 4$ activation. Bioresource technology.2011;102:36458. $\leq \mathrm{DOl}>$

13. Foo K, Hameed B, Microwave-assisted preparation of oil palm fiber activated carbon for methylene blue adsorption. Chemical Engineering Journal. 2011;166:792-5. <DOl>

14. Gonzalez JF, Roman S, González-García CM, Nabais JV, Ortiz AL. Porosity development in activated carbons prepared from walnut shells by carbon dioxide or steam activation. Industrial engineering chemistry research. 2009;48:7474-81. $\leq \mathrm{DOI}>$

15. Chen $Y$, Zhu $Y$, Wang $Z$, Li $Y$, Wang $L$, Ding $L$, Gao X, Ma Y, Guo Y. Application studies of activated 
carbon derived from rice husks produced by chemical-thermal process-A review, Advances in colloid interface science, 2011;163:39-52. <DOl>

16. Demirbas E, Kobya M, Sulak M. Adsorption kinetics of a basic dye from aqueous solutions onto apricot stone activated carbon. Bioresource technology. 2008;99:5368-73. $\leq \mathrm{DOI}>$

17. Angin D. Production and characterization of activated carbon from sour cherry stones by zinc chloride. Fuel. 2014;115:804-11. $\leq \mathrm{DOl}>$

18. Van Thuan T, Quynh BTP, Nguyen TD, Bach LG. Response surface methodology approach for optimization of $\mathrm{Cu}^{2+}, \mathrm{Ni}^{2+}$ and $\mathrm{Pb}^{2+}$ adsorption using $\mathrm{KOH}$-activated carbon from banana peel. Surfaces Interfaces. 2017;6:209-17. $\leq \mathrm{DOl}>$

19. Srinivasakannan C, Bakar MZA. Production of activated carbon from rubber wood sawdust.

Biomass and Bioenergy.2004;27;89-96. <DOl>

20. Suzuki R, Andrade A, Sousa J, Rollemberg M. Preparation and characterization of activated carbon from rice bran. Bioresource technology.

2007; 98:1985-91. <DOI>

21. Mohan D, Sarswat A, Singh VK, AlexandreFranco M, Pittman Jr. C. Development of magnetic activated carbon from almond shells for trinitrophenol removal from water. Chemical

Engineering Journal. 2011;172:1111-25. <DOl>

22. Yagmur E, Ozmak M, Aktas Z. A novel method for production of activated carbon from waste tea by chemical activation with microwave energy. Fuel.

2008;87:3278-85. <DOI>

23. Yang J, Qiu K. Development of high surface area mesoporous activated carbons from herb residues. Chemical engineering journal. 2011;167:148-54.

$\langle\mathrm{DOl}>$
24. Bagheri N, Abedi J, Adsorption of methane on corn cobs based activated carbon. Chemical Engineering Research Design. 2011;89:2038-43. $\leq \mathrm{DOI}>$

25. Teker M, Saltabaş Ö, İmamoğlu M. Adsorption of cobalt by activated carbon from the rice hulls. Journal of Environmental Science Health Part A. 1997;32:2077-86. $\leq$ DOl>

26. Krishnan KA, Anirudhan T. Uptake of heavy metals in batch systems by sulfurized steam activated carbon prepared from sugarcane bagasse pith. Industrial Engineering Chemistry Research.

2002;41:5085-93. $\leq$ DOl $>$

27. Deng H, Zhang G, Xu X, Tao G, Dai J. Optimization of preparation of activated carbon from cotton stalk by microwave assisted phosphoric acidchemical activation. Journal of Hazardous Materials. 2010;182:217-24. <DOI>

28. Fernandez ME, Nunell GV, Bonelli PR, Cukierman AL. Activated carbon developed from orange peels: Batch and dynamic competitive adsorption of basic dyes. Industrial Crops Products. 2014;62:437-45. $\leq$ DOI $>$

29. Alhamed YA. Adsorption kinetics and performance of packed bed adsorber for phenol removal using activated carbon from dates' stones. Journal of Hazardous Materials. 2009;170:763-70.

$\leq \mathrm{DOI}>$

30. Gupta VK, Jain R, Shrivastava M, Nayak A. Equilibrium and thermodynamic studies on the adsorption of the dye tartrazine onto waste "coconut husks" carbon and activated carbon. Journal of Chemical Engineering Data. 2010;55:5083-90. $\leq \mathrm{DOI}>$

31. Pallares J, Cencerrado GA, Arauzo I. Production and characterization of activated carbon from barley straw by physical activation with carbon dioxide and steam. Biomass and Bioenergy. 2018;115:64-73.

$\leq \mathrm{DOI}>$ 
32. Jurado-Sanchez B, Sattayasamitsathit S, Gao W, Santos L, Fedorak Y, Sing Vv, Orozco J, Galarnyk M, Wang J. Self-Propelled Activated Carbon Janus Micromotors for Efficient Water Purification. Small. 2015;11:499-506. <DOI>

33. Matsuo T, Nishi T. Activated carbon filter treatment of laundry waste water in nuclear power plants and filter recovery by heating in vacuum.

Carbon. 2000;38(5):709-14. <DOI>

34. Sircar S, Golden T, Rao M. Activated carbon for gas separation and storage. Carbon. 1996;34(1):112. $\leq \mathrm{DOI}>$

35. Fang B, Binder L. A modified activated carbon aerogel for high-energy storage in electric double layer capacitors. Journal of power sources.

2006;163; 616-22. <DOI>

36. Faria P, Órfão J, Pereira M. Activated carbon catalytic ozonation of oxamic and oxalic acids. Applied Catalysis B: Environmental. 2008;79:23743. $\leq \mathrm{DOI}>$

37. Rivera-Utrilla J, Sánchez-Polo M, GómezSerrano V, Alvarez P, Alvim-Ferraz M, Dias J. Activated carbon modifications to enhance its water treatment applications. An overview. Journal of hazardous materials. 2011;187:1-23. <DOl>

38. Snyder AS, Adham S, Redding AM, Cannon FS, Decarolis J, Oppenheimer J, Wert EC, Yoon Y. Role of membranes and activated carbon in the removal of endocrine disruptors and pharmaceuticals, Desalination, 2007;202:156-81. <DOI>

39. Park JH, Park OO. Hybrid electrochemical capacitors based on polyaniline and activated carbon electrodes. Journal of Power Sources. 2002;111:185-0. <DOI>

40. Anirudhan T, Sreekumari S, Bringle C. Removal of phenols from water and petroleum industry refinery effluents by activated carbon obtained from coconut coir pith. Adsorption. 2009;15;439. <DOI>

41. Vargas AM, Cazetta AL, Kunita $M H$, Silva $T L$, Almeida VC. Adsorption of methylene blue on activated carbon produced from flamboyant pods (Delonix regia): Study of adsorption isotherms and kinetic models. Chemical Engineering Journal. 2011;168:722-30. <DOI>

42. Anyika C, Asri NAM, Majid ZA, Yahya A, Jaafar J. Synthesis and characterization of magnetic activated carbon developed from palm kernel shells. Nanotechnology for Environmental Engineering. 2017; 2: 16. <DOI>

43. Prauchner JM, Sapag K, Reinoso RF. Tailoring biomass-based activated carbon for $\mathrm{CH} 4$ storage by combining chemical activation with $\mathrm{H} 3 \mathrm{PO} 4$ or $\mathrm{ZnCl} 2$ and physical activation with $\mathrm{CO} 2$. 2016;110:138-47. <DOI> 
Küçük İ, Önal Y. JOTCSA. 2021; 8(3): 821-834. 